\title{
A widespread transposable element masks expression of a yeast copper transport gene
}

\author{
Simon A.B. Knight, Simon Labbé, Lucy F. Kwon, Daniel J. Kosman, ${ }^{1}$ and Dennis J. Thiele ${ }^{2}$ \\ Department of Biological Chemistry, University of Michigan Medical School, Ann Arbor, Michigan 48109-0606 USA; \\ ${ }^{1}$ Department of Biochemistry, School of Medicine and Biomedical Sciences, State University of New York, Buffalo, New \\ York 14214 USA
}

\begin{abstract}
The trace element copper $(\mathrm{Cu})$ is essential for cell growth. In this report we describe the identification of a new component of the high-affinity $\mathrm{Cu}$ transport machinery in yeast, encoded by the CTR3 gene. Ctr3p is a small intracellular cysteine-rich integral membrane protein that restores high-affinity $\mathrm{Cu}$ uptake, $\mathrm{Cu}, \mathrm{Zn}$ superoxide dismutase activity, ferrous iron transport, and respiratory proficiency to strains lacking the CTR1 (Cu transporter 1) gene. In most commonly used Saccharomyces cerevisiae laboratory strains, expression of CTR3 is abolished by a Ty2 transposon insertion that separates the CTR3 promoter from the transcriptional start sites by $6 \mathrm{~kb}$. In strains that do not possess a Ty2 transposon at the CTR3 locus, expression of CTR3 is repressed by copper and activated by copper starvation. In such strains inactivation of both $C T R 1$ and $C T R 3$ is required to generate lethal copper-deficient phenotypes. Although $\mathrm{Ctr1p}$ and $\mathrm{Ctr} 3 \mathrm{p}$ can function independently in copper transport, the expression of both proteins provides maximal copper uptake and growth rate under copper-limiting conditions. These results underscore the importance of mobile DNA elements in the alteration of gene function and phenotypic variation.
\end{abstract}

[Key Words: Copper; transport; yeast; transposon; transcription]

Received May 1, 1996; revised version accepted June 19, 1996.

The trace element copper $(\mathrm{Cu})$ is an essential cellular redox component required for catalysis by a wide variety of enzymes such as $\mathrm{Cu}, \mathrm{Zn}$ superoxide dismutase $/ \mathrm{Cu}$, Zn SOD|, lysyl oxidase, cytochrome $c$ oxidase, and dopamine $\beta$ hydroxylase (Linder 1991). Ironically, the same redox-active nature of $\mathrm{Cu}$ renders it extremely cytotoxic, attributable to its ability to engage in chemical reactions that generate hydroxyl radicals. This radical causes lipid peroxidation, nucleic acid cleavage, and direct protein damage (Halliwell and Gutteridge 1984; Stadtman and Oliver 1991). Therefore, it is critical that all cells acquire sufficient $\mathrm{Cu}$ for essential biochemical reactions, yet prevent the accumulation of $\mathrm{Cu}$ to toxic levels.

Yeast cells have provided a tractable genetic system in which to identify and analyze components that make up the cellular $\mathrm{Cu}$ homeostatic machinery. In response to high levels of exogenous $\mathrm{Cu}$, the baker's yeast Saccharomyces cerevisiae activates transcription of the metallothionein genes CUP1 and CRS5, which encode low molecular weight, cysteine-rich, Cu-binding/detoxification proteins (Culotta et al. 1994; Zhu et al. 1995). Curesponsive gene activation occurs through cis-acting $\mathrm{Cu}$ responsive elements and the trans-acting $\mathrm{Cu}$-activated

${ }^{2}$ Corresponding author. metalloregulatory transcription factor Acelp (Zhu et al. 1995). Under low environmental $\mathrm{Cu}$ conditions yeast cells accumulate $\mathrm{Cu}$ by the reduction of $\mathrm{Cu}$ (II) to $\mathrm{Cu}(\mathrm{I})$, catalyzed by the extracellular $\mathrm{Fe}(\mathrm{III}) / \mathrm{Cu}$ (II) reductases Frelp and Fre2p, encoded by the FRE1 and FRE2 genes, respectively (Dancis et al. 1992; Georgatsou and Alexandraki 1994; Hassett and Kosman 1995). Cu enters the cell through a high-affinity transport system, an important component of which is encoded by the CTR 1 gene (Dancis et al. 1994b). The Ctrl protein is localized to the plasma membrane and contains 11 putative $\mathrm{Cu}$-binding motifs (Met- $X_{2}-$ Met) that resemble those found in prokaryotic $\mathrm{Cu}$ homeostasis proteins (Cha and Cooksey 1991; Odermatt et al. 1993; Dancis et al. 1994b). In response to elevated extracellular $\mathrm{Cu}$ levels, expression of both the CTR1 and FRE1 genes is repressed, as would be expected for loci encoding proteins that have important roles in high-affinity Cu transport (Dancis et al. 1994a; Hassett and Kosman 1995).

Elegant studies have uncovered an important link between $\mathrm{Cu}$ availability and Fe transport in S. cerevisiae. Yeast strains harboring a deletion of the CTR1 gene (ctr1 $1 \Delta)$ are defective in ferrous iron uptake, attributable to a failure to provide $\mathrm{Cu}$ to a multi-Cu Fe oxidase, Fet3p (Askwith et al. 1994; Dancis et al. 1994b). Fet3p is structurally similar to the human serum Cu-binding protein 
ceruloplasmin and is required for high-affinity iron accumulation (Askwith et al. 1994; De Silva et al. 1995; Stearman et al. 1996). Furthermore, $\operatorname{ctr} 1 \Delta$ strains display a number of other phenotypes associated with $\mathrm{Cu}$ deficiency, including defective high-affinity $\mathrm{Cu}$ transport, poor growth on low $\mathrm{Cu}$ medium, deficient $\mathrm{Cu}, \mathrm{Zn}$ SOD activity with a concomitant sensitivity to oxidative stress, inability to grow on respiratory carbon sources, and an inability to activate CUP1 gene transcription through the Acelp $\mathrm{Cu}$ metalloregulatory factor, except at very high exogenous $\mathrm{Cu}$ concentrations (Dancis et al. 1994a,b).

Although little is known about the complexity and organization of prokaryotic or eukaryotic Cu transporters, many ion transporters are composed of a complex array of polypeptides that are either directly involved in ion transport or that modify the function of the transport machinery (Catterall 1995; Vulpe and Packman 1995). To identify additional components of the $\mathrm{Cu}$ transport machinery, we isolated mutants that allow yeast cells to dispense with the Ctrl protein, yet maintain high-affinity $\mathrm{Cu}$ uptake. One such mutation, $C T R 3^{\mathrm{s}}$, restores highaffinity $\mathrm{Cu}$ and $\mathrm{Fe}$ transport, growth on nonfermentable carbon sources, $\mathrm{Cu}, \mathrm{Zn}$ SOD activity and other phenotypes associated previously with the loss of Ctrl protein. The Ctr3 protein is an intracellular membrane protein, the expression of which is up-regulated in response to copper starvation and repressed by exogenous $\mathrm{Cu}$. Interestingly, expression of the CTR3 gene is abrogated in the large majority of commonly used strains of $S$. cerevisiae, through a transposon insertion within the CTR3 promoter. Yeast cells that express both the CTR1 and CTR3 genes have a distinct growth advantage, when $\mathrm{Cu}$ is limiting, over cells expressing either one of these $\mathrm{Cu}$ transporters alone. These results demonstrate that the presence of mobile DNA elements within the genome of many widely used laboratory strains of yeast provide an important mechanism for phenotypic variation under specific physiological conditions.

\section{Results}

\section{A mutation in CTR3 restores high-affinity $\mathrm{Cu}$ transport}

Yeast strains harboring an inactivated CTR1 gene exhibit a spectrum of phenotypes, including the inability to grow on nonfermentable carbon sources, which can be corrected by the addition of $\mathrm{Cu}$ to the growth medium (Dancis et al. 1994b). To identify additional components of the yeast high-affinity $\mathrm{Cu}$ transport system, we used ethylmethane sulfonate (EMS) mutagenesis to isolate yeast cells that can respire in the absence of the Ctrl protein. The CTR1 gene was inactivated in the $S$. cerevisiae strain SEY6210 (CTR1 CTR3) to generate a $c t r 1 \Delta$ strain (ctr1 $\triangle C T R 3)$ and this strain was treated with EMS. Of $5 \times 10^{8}$ colonies that survived the EMS mutagenesis, one mutant designated $C T R 3^{\text {s }}$, was isolated which grew on YPE medium (ethanol as sole carbon source) (Fig. 1A; $c t r 1 \triangle C T R 3^{s}$ ). This mutant is also resistant to oxidative stress, initiated by the superoxide-
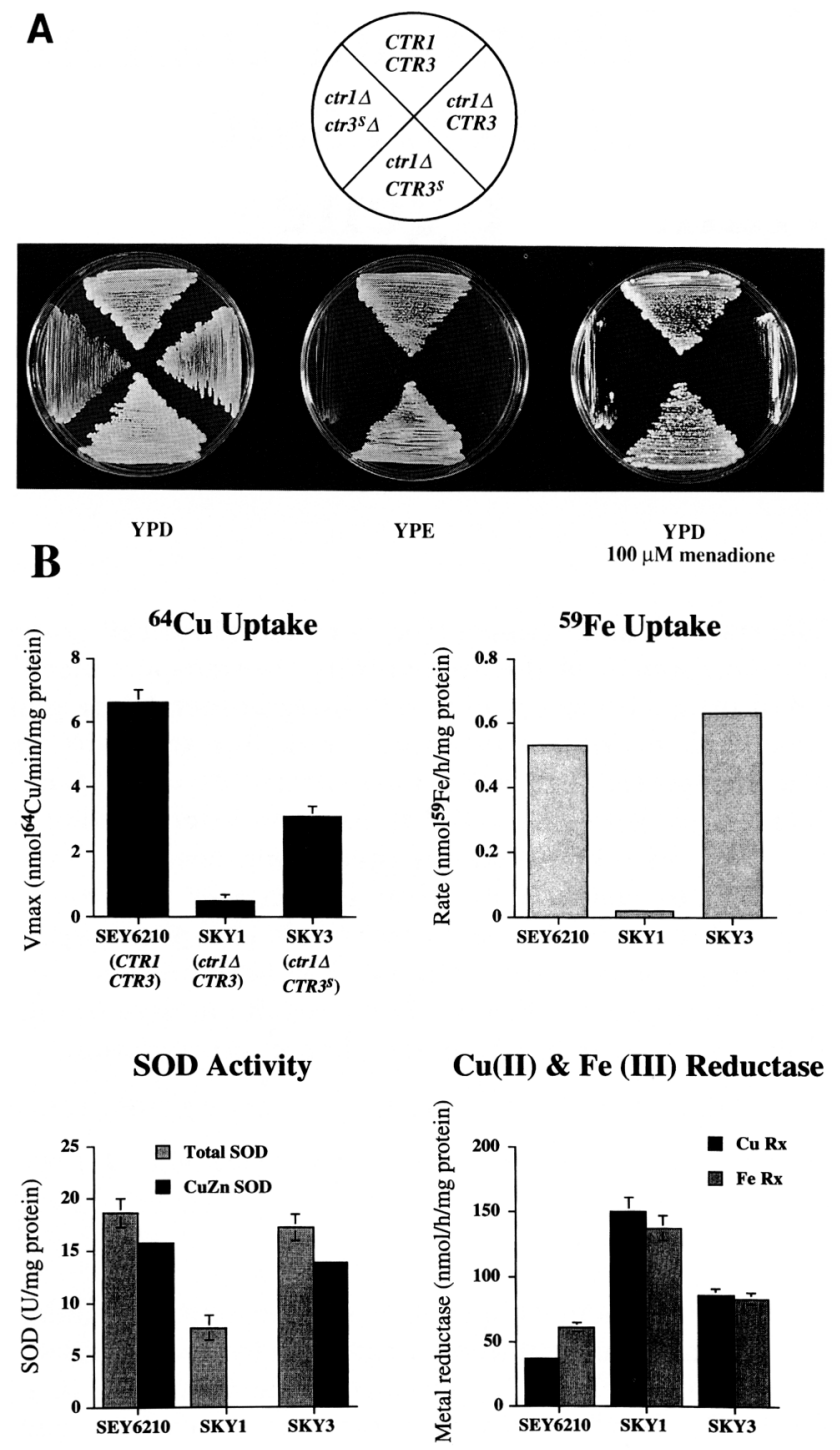

Figure 1. CTR 3 s suppresses phenotypes associated with a ctr1 deletion. (A) Strains SEY6210 (CTR1 CTR3), SKY1 (ctr1A $C T R 3), \mathrm{SKY} 3\left(c \operatorname{ct} 1 \Delta C T R 3^{\mathrm{s}}\right)$, and SKY12 (ctr1 $\left.C T R 3^{\mathrm{s}} \Delta\right)$ were grown on YPD, YPE, and YPD containing $100 \mu \mathrm{M}$ menadione. The YPD and YPD-menadione plates were photographed after 2 days incubation at $30^{\circ} \mathrm{C}$ and the YPE plate was photographed after 4 days. $(B){ }^{64} \mathrm{Cu}$ uptake in strains SEY6210, SKY1, and SKY3. ${ }^{64} \mathrm{Cu}$ uptake $\left(V_{\max }\right)$ was calculated from radioactive isotope accumulated during 3-min incubations, under high-affinity transport conditions. ${ }^{59} \mathrm{Fe}$ uptake rate was determined from radioactive isotope accumulated during a 20 -min incubation. Cell-surface reductase activities were calculated from the absorbance change associated with the reduced forms of each metal. SOD activity, determined by inhibition of superoxide anion generation, is shown as total SOD activity and $\mathrm{Cu}, \mathrm{Zn}$ SOD activity. Error bars represent the standard deviation for three independent experiments.

generating drug menadione and grew at high oxygen concentrations (Fig. 1A; data not shown). A diploid generated from a cross between the CTR $3^{\mathrm{s}}$ suppressor strain 
and a strain of the opposite mating type bearing a $\operatorname{ctr} 1 \Delta$ disruption grew on YPE, demonstrating that the $C T R 3^{\mathrm{s}}$ mutation acts in a dominant fashion. Sporulation of the diploid and genetic analysis of 10 complete tetrads demonstrated that the $C T R 3^{\mathrm{s}}$ suppressor mutation segregates as a single Mendelian locus (data not shown).

Because $c t r 1 \Delta$ strains possess a number of $\mathrm{Cu}$-remedial phenotypes, we ascertained whether the $C T R 3^{\text {s }}$ allele is capable of suppressing all of the phenotypes associated previously with $\operatorname{ctr} 1 \Delta$ strains (Dancis et al. 1994a,b). As shown in Figure 1B, inactivation of the CTR1 gene, in strain SEY6210, resulted in a $>90 \%$ reduction in highaffinity ${ }^{64} \mathrm{Cu}$ transport (cf. SEY6210 to SKY1). In the ctr1 CTR3 $^{\mathrm{s}}$ strain (SKY3) high-affinity $\mathrm{Cu}$ transport was restored to $\sim 50 \%$ that of the wild-type starting strain, a level sufficient for growth on respiratory carbon sources (Fig. 1A). ${ }^{59} \mathrm{Fe}$ uptake, almost undetectable in the ctr1 $1 \Delta$ mutant, was restored to wild-type levels in cells harboring the $C T R 3^{\mathrm{s}}$ allele (Fig. 1B). Additionally, cells bearing the $C T R 3^{\mathrm{s}}$ allele (SKY3) have nearly wild-type levels of $\mathrm{Cu}, \mathrm{Zn}$ SOD activity, whereas the $\operatorname{ctr} 1 \Delta$ strain, as observed previously by Dancis et al. (1994), was devoid of measurable $\mathrm{Cu}, \mathrm{Zn}$ SOD activity (Fig. 1B). Therefore, although the $C T R 3^{\text {s }}$ mutation restores the highaffinity $\mathrm{Cu}$ uptake rate to $50 \%$ that of the wild-type starting strain, this level of uptake provides sufficient $\mathrm{Cu}$ for high-affinity Fe uptake, for normal $\mathrm{Cu}, \mathrm{Zn}$ SOD activity, and growth in the presence of the superoxide anion-generating drug menadione. Moreover, although the ctr1 $1 \Delta$ mutation increases the activity of the $\mathrm{Cu} / \mathrm{Fe}$ reductase more than twofold, presumably as a consequence of $\mathrm{Cu}$ and $\mathrm{Fe}$ starvation, reductase activity in the $C T R 3^{s}$ background is reduced nearly to that found in the wild-type parental strain (Fig. 1B). The inability to lower reductase activity completely to wild-type levels may be attributable to a partial $\mathrm{Cu}$ starvation, as the $\operatorname{ctr} 1 \Delta$ $C T R 3^{\mathrm{s}}$ strain only restores $\mathrm{Cu}$ transport to $50 \%$ the level of the starting strain. Taken together, these results and those described below establish that the CTR $3^{\mathrm{s}}$ mutation restores high-affinity $\mathrm{Cu}$ transport to a rate that is sufficient to provide $\mathrm{Cu}$ for normal biochemical and growth functions in a $c t r 1 \Delta$ strain.

\section{Isolation and characterization of CTR3}

Based on the dominant nature of the $C T R 3^{\text {s }}$ mutation, we isolated the $C T R 3^{\text {s }}$ locus by constructing a singlecopy DNA library from a partial Sau3A digestion of genomic DNA from the $c t r 1 \triangle C T R 3^{\mathrm{s}}$ strain SKY3 (Ausubel et al. 1987). The ctr1 1 parental strain was transformed directly with the ligation mixture and transformants were replica-plated to YPE medium. Plasmid DNA was isolated from two $\mathrm{YPE}^{+}$transformants by retrieval into Escherichia coli cells, and retransformation of the ctr1 strain demonstrated that the $\mathrm{YPE}^{+}$phenotype was plasmid-dependent. Restriction enzyme digestion demonstrated that these two plasmids contained nonidentical genomic DNA fragments that shared a $3.5-\mathrm{kb} X b a \mathrm{I}$ DNA fragment. This fragment was further digested and DNA fragments were subcloned into the single-copy plasmid
pRS315 (Sikorski and Hieter 1989). In vivo complementation analysis demonstrated that a 1.4-kb HpaI-XbaI DNA fragment harbored the full suppression activity of the $C T R 3^{\text {s }}$ allele (data not shown).

DNA sequence analysis of the 1.4-kb HpaI-XbaI fragment revealed a 723-nucleotide-long open reading frame (ORF) with $100 \%$ sequence identity to an ORF, of unknown function, identified in the $S$. cerevisiae genome sequencing project of chromosome XII ( $\mathrm{M}$. Johnston, unpubl. ORF L9931.6). The CTR3 ${ }^{\text {s }}$ ORF encodes a polypeptide of 241 amino acids with a predicted molecular mass of $27.5 \mathrm{kD}$ (Fig. 2A). This coding region is essential for $C T R 3^{\mathrm{s}}$ function because disruption of the ORF abolishes the suppression of the respiratory defect, oxidative stress sensitivity (Fig. $1 \mathrm{~A} ; \operatorname{ctr} 1 \Delta C T R 3^{\mathrm{s}} \Delta$ ) and other phenotypes (data not shown) associated with the $\operatorname{ctr} 1 \Delta$ mutation. Several features of the Ctr3p sequence are noteworthy. Ctr3p contains two potential asparagine-linked glycosylation sites and two potential membrane-spanning regions identified using the TMpred program (Hofmann and Stoffel 1993) (Fig. 2A). Furthermore, Ctr3p contains 11 cysteine residues, three pairs of which are in potential metal coordination arrangements Cys-Cys or Cys- $X_{2}-$ Cys (Winge et al. 1985), however, at present it is unknown whether these residues interact directly with metals. A direct alignment of the amino acid sequences of Ctr3p with Ctrlp only identified a short stretch of similarity between the first seven amino-terminal residues of Ctr3p (MNMGGSS) and a sequence (MNMGSS) of Ctrlp four residues from the amino terminus. Comparison of Ctr3p with sequences currently in the data base revealed homology ( $25 \%$ identity, $53 \%$ similarity) with Ctr2p, a protein of 189 amino acids identified as a yeast homolog to a putative $\mathrm{Cu}$ transport protein, COPT1, of Arabidopsis thaliana (Kampfenkel et al. 1995). The potential role of Ctr2p-mediated Cu uptake in yeast cells, however, has not yet been ascertained.

\section{The presence of a Ty2 transposon eliminates CTR3 expression}

Although $C T R 3^{\mathrm{s}}$ is a dominant mutation, we observed no sequence differences in the ORF between our genomic DNA isolate and the sequence reported in the yeast genome project for this locus derived from the most commonly used wild-type $S$. cerevisiae laboratory strain, S288C (Mortimer and Johnston 1986). However, comparison of the sequence of these loci in the promoter regions revealed that in $\mathrm{S} 288 \mathrm{C}$, a 6-kb Ty2 transposon is present $105 \mathrm{bp}$ upstream of the initiator AUG of the CTR3 ORF (Fig. 2B; Ty2::CTR3 sequence). In the cloned CTR3 ${ }^{\text {s }}$ gene, the majority of the Ty2 element was absent, with only 25 nucleotides derived from the $3^{\prime}$ terminus of the Ty2 $\delta$ element, flanked by a repeated 5'-CTTCT-3' sequence present (Fig. $2 \mathrm{~B} ;$ CTR $3^{\mathrm{s}}$ sequence). Immediately upstream and downstream of these 25 nucleotides, the sequence of the CTR $3^{\mathrm{s}}$ locus is identical to that described for S288C for at least several hundred nucleotides, demonstrating that the only mutation at this locus is the absence of most of the Ty2 element. As de- 
A

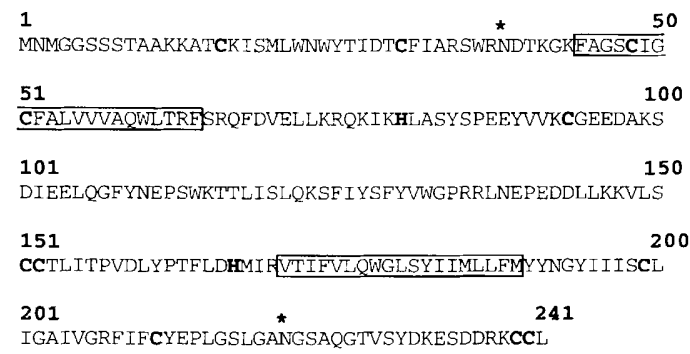

B

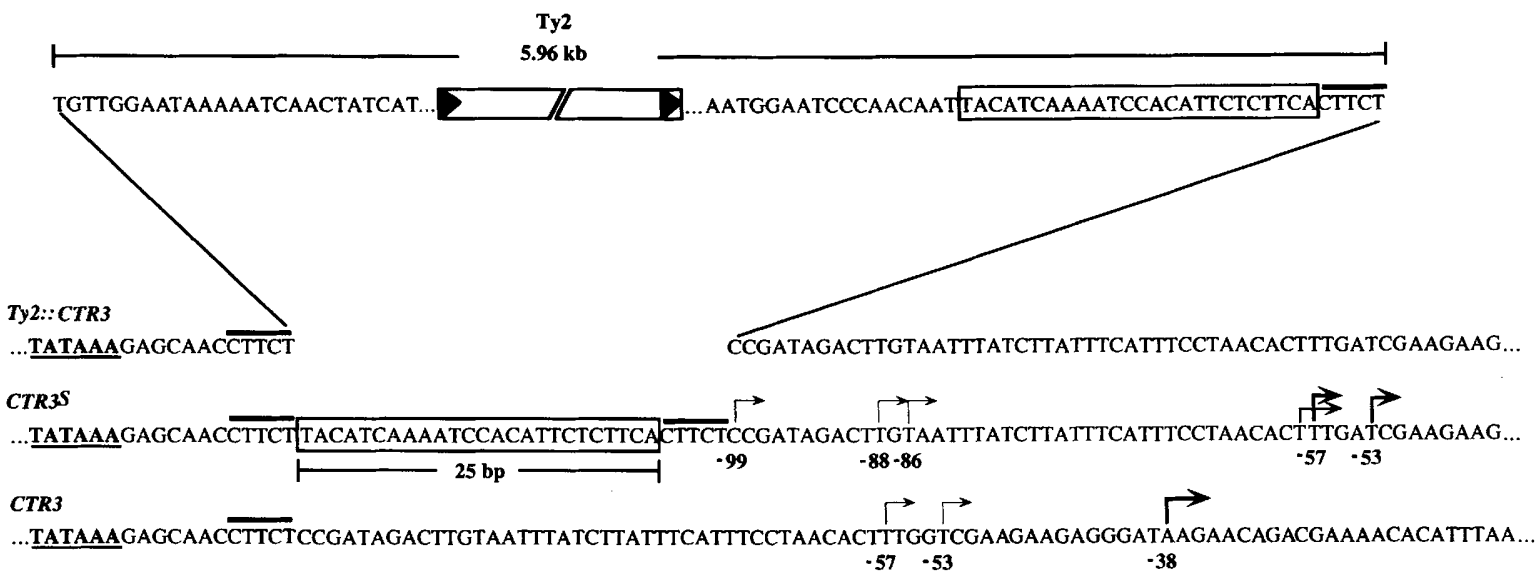

Figure 2. Ctr3 protein sequence and CTR3 allele structure. (A) Predicted amino acid sequence of Ctr3p. The 11 cysteines and 2 histidines are in bold. Asterisks indicate the two putative asparagine-glycosylation sites and the boxed residues are predicted transmembrane regions. $(B)$ Wild-type and mutant CTR3 loci. DNA sequence Ty2::CTR3 corresponds to the allele present in S288C and SEY6210 in which the putative TATA box (underscored) is displaced $\sim 6 \mathrm{~kb}$ by the Ty2 element. The CTR $3^{\mathrm{s}}$ DNA sequence corresponds to the $c t r 1 \Delta$ suppressor mutation (strain SKY3) in which the Ty2 element has been excised leaving 25 bp of the $\delta$ element (boxed sequence) and shifting the TATA element adjacent to the CTR3 ORF. The CTR3 DNA sequence is the allele present in BR10 that does not have a Ty2 element at this locus. The overlined sequences show the site of insertion of the Ty2 element. Bold and thin arrows represent major and minor transcriptional start sites, respectively, and mark the direction of transcription. The numbers below the arrows indicate the positions of these start sites upstream from the ATG of the ORF.

scribed below, both the SEY6210 and SKY1 (ctr1A) strains harbor a Ty2 at the same position within CTR3 as is found in $\mathrm{S} 288 \mathrm{C}$. The Ty2 insertion into the CTR3 promoter region is in the same orientation as the CTR3 gene, and is predicted to separate the putative promoter and TATA box from the ORF by $6 \mathrm{~kb}$. Although this TATAAA sequence has not been demonstrated to function in CTR3 gene transcription, this is the only TATA box consensus sequence (Hahn et al. 1989) within $200 \mathrm{bp}$ upstream of the CTR3 ORF. Additionally, primer extension analysis identified the major start sites for $C T R 3^{\mathrm{s}}$ transcription in the $\operatorname{ctr} 1 \triangle C T R 3^{\mathrm{s}}$ strain to positions -57 and -53 with respect to the AUG that initiates this ORF, with four minor start sites upstream of these (Fig. $2 \mathrm{~B}$; sequence $C T R 3^{\text {s }}$. These correspond to positions 84 and 88 nucleotides downstream of the proposed TATAA element and are consistent with this element serving as the functional CTR3 TATA box. These CTR3 transcriptional start sites are slightly shifted in a strain for which there is no sequence evidence for a CTR3-associated Ty2 element (Fig. 2B; sequence CTR3), suggesting that the residual 25 nucleotides of the Ty2 sequence downstream of the TATAAA sequence in the $C T R 3^{\text {s }}$ gene have shifted the start sites for transcription (Fig. 2B; sequence CTR3). Taken together, these results strongly suggest that the presence of the Ty2 element in the CTR3 promoter abrogates CTR3 transcription because of the separation of the promoter from the transcriptional initiation sites by $6 \mathrm{~kb}$. Excision of the Ty 2 element, through an unknown mechanism, results in the juxtaposition of the promoter and putative TATA element to the transcription initiation sites.

The insertion of transposable elements adjacent to ORFs is well established to modulate flanking gene expression in prokaryotes and eukaryotes (Roeder and Fink 1983; Kleckner 1989; Boeke and Sandmeyer 1991). Therefore, we examined the structure of the CTR3 promoter in the isogenic wild-type parental strain SEY6210, 
the $\operatorname{ctr} 1 \Delta$ strain SKY1, and the $\operatorname{ctr} 1 \triangle C T R 3^{\mathrm{s}}$ strain SKY3 and compared the steady-state levels of CTR3 mRNA in these backgrounds by RNA blotting. As shown in Figure 3, CTR3 mRNA levels were undetectable in both SEY6210 and SKY1 and there was no change when cells were either treated with $\mathrm{Cu}$, the $\mathrm{Cu}$ chelator bathocuproine disulfonate $\langle\mathrm{BCS}\rangle$, or the $\mathrm{Cu} / \mathrm{Fe}$ chelator bathophenanthroline disulfonate (BPS). The weak background hybridization band represents cross-reactivity with the $18 \mathrm{~S}$ ribosomal RNA, slightly larger than CTR3 mRNA. In contrast, in the isogenic CTR $3^{s}$ strain SKY3, CTR3 mRNA levels were detectable in control cultures, repressed by the addition of $\mathrm{Cu}$ concentrations as low as $1 \mu \mathrm{M}$ and derepressed $\sim 20$-fold, as determined by phosphorimager analysis, when cells were treated with the copper and iron/copper chelators BCS and BPS (Fig. 3; ctr1 $\left.C C T R 3^{\mathrm{s}}\right)$. As expected, CUP1 mRNA levels were induced by $\mathrm{Cu}$ in a dose-dependent manner in the CTR 1 wild-type strain but were only induced with high $\mathrm{Cu}$ levels in the $c t r 1 \Delta$ strain. Consistent with the restoration of high-affinity $\mathrm{Cu}$ transport in the $\operatorname{ctr} 1 \triangle C T R 3^{\mathrm{s}}$ strain, CUP1 mRNA levels were induced in a Cu dosedependent manner (Fig. 3). Therefore, the CTR $3^{\mathrm{s}}$ mutation permits expression of the CTR3 locus, strongly suggesting that insertion of the Ty2 element prevents transcription of CTR3 and that excision of the Ty2 transposon restores gene expression and $\mathrm{Cu}$ regulation.

To determine whether a correlation exists between the absence of a Ty element within the CTR3 locus and CTR3 mRNA expression, we analyzed several common laboratory strains of $S$. cerevisiae for the presence of Ty2 adjacent to CTR3 and measured CTR3 mRNA levels (Fig. 4). Of 15 laboratory strains examined by Southern blotting and PCR, only three had no Ty element associated with CTR3. The data in Figure 4 show such an analysis for five different strains, two of which lacked the Ty2 element [SKY3(CTR3 $3^{s}$ mutant) and BR10] and three of which had the Ty2 located within the CTR3 promoter region (SEY6210, SKY1, S288C). The presence of an XbaI restriction site in the Ty2 element permitted a convenient analysis; strains with a Ty2 element in the CTR3

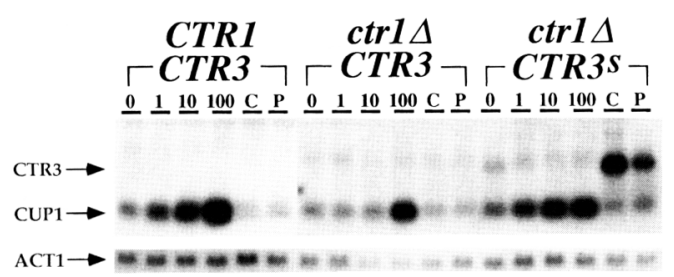

Figure 3. CTR 3 mRNA is expressed from the $C T R 3^{\mathrm{s}}$ allele and regulated by cellular Cu status. Strains SEY6210 (CTR1 CTR3),

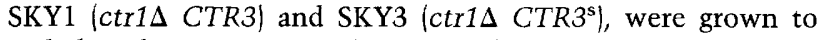
early log-phase in YPD media. $\mathrm{CuSO}_{4}(0,1,10$, and $100 \mu \mathrm{M}), 100$ $\mu \mathrm{M}$ BCS $(\mathrm{C})$, or $100 \mu \mathrm{M}$ BPS (P) were added and after a 3 -hr incubation at $30^{\circ} \mathrm{C}$ total RNA was isolated. Shown is an RNA blot of CTR3, CUP1, and ACT1 mRNA steady-state levels indicated by arrows. Results shown are representative of three independent experiments.
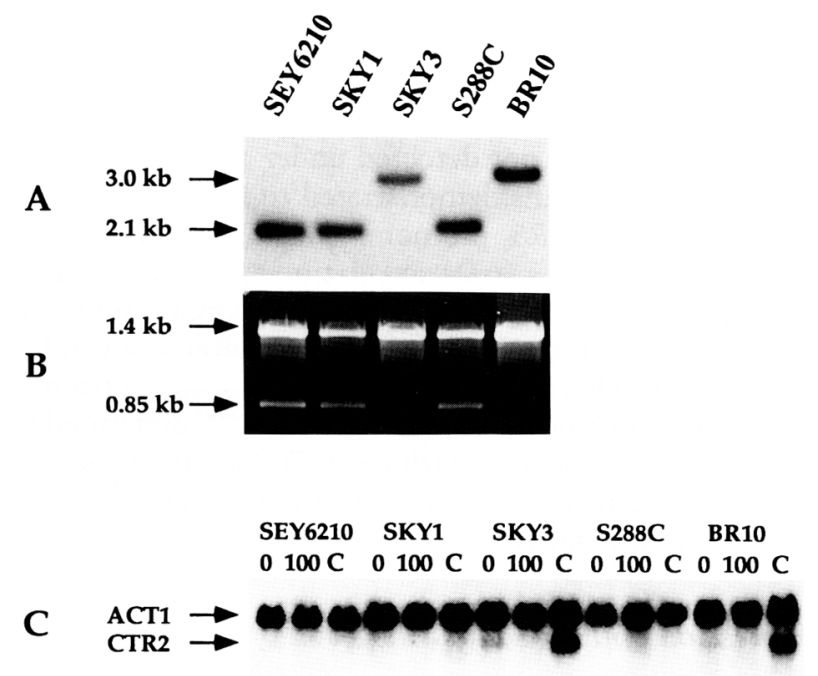

Figure 4. A Ty2 element prevents CTR3 expression in many yeast strains. $(A)$ Southern blot analysis for the presence or absence of the CTR3-associated Ty2 element. Genomic DNA isolated from S. cerevisiae strains SEY6210, SKY1, SKY3, S288C, and BR10 was digested with $\mathrm{XbaI}$ and probed with ${ }^{32} \mathrm{P}$-labeled DNA derived from the CTR3-coding region. The $3.0-\mathrm{kb}$ fragment indicates absence of the Ty2 element and the $2.1-\mathrm{kb}$ fragment indicates the presence of a Ty2 element adjacent to the CTR3-coding region. (B) PCR confirmation of the Ty2 status within the CTR3 locus. Synthetic DNA oligonucleotides representing a sequence from the Ty2 element and the CTR3 ORF were used in PCR procedures. The presence of a $0.85-\mathrm{kb}$ PCR product indicates the presence of a Ty2 element within the CTR3 promoter. The 1.4-kb DNA PCR product was produced from synthetic DNA oligonucleotides designed to amplify the FRE1 gene and included in the PCR as a positive control. $(C)$ The five strains that were analyzed in $A$ and $B$ were grown in YPD to early log phase. Cu $(100 \mu \mathrm{M}), \mathrm{BCS}(\mathrm{C}, 100 \mu \mathrm{M})$, or nothing $\{0 \mid$ was added, and the cells were incubated for $3 \mathrm{hr}$ after which total RNA was isolated. Shown is an autoradiograph of an RNA blot of CTR3 and ACT1 mRNA steady-state levels, indicated with arrows.

promoter gave rise to a $2.1-\mathrm{kb}$ band by Southern blotting, whereas strains without the Ty2 element give a $3.0-\mathrm{kb}$ DNA fragment (Fig. 4A). To verify that the size differences observed by Southern blotting were attributable to a Ty2 insertion rather than another polymorphism, PCR analysis was carried out using one primer specific to the CTR3-coding region and a second primer that specifically hybridizes with Ty2 DNA (Fig. 4B). The amplification of the expected $0.85-\mathrm{kb}$ PCR product using genomic DNA from the strains that were Ty2 positive by Southern blotting, but not those that were negative, confirmed the presence of the Ty2 element in the CTR3 promoter of these three strains. The $1.4-\mathrm{kb}$ fragment corresponds to the product from primers included as a positive control for PCR (Fig. 4B). Expression from the CTR3 locus in the same strains was examined by RNA blotting. These experiments demonstrated that the strains lacking a CTR3-associated Ty2 element, SKY3 and BR10, express detectable CTR3 mRNA under control growth condi- 
tions (Fig. 4C). CTR3 mRNA expression in these strains is repressed in cultures exposed to $100 \mu \mathrm{M} \mathrm{Cu}$ (Fig. 4, lanes 100) and highly induced in cultures starved for $\mathrm{Cu}$ by treatment with the Cu chelator BCS (Fig. 4, lanes C). CTR3 mRNA was not detected under any of these conditions in the strains demonstrated to harbor a Ty2 element in the CTR3 promoter (SEY6210, SKY1, and $\mathrm{S} 288 \mathrm{C}$ ). Therefore, a strict correlation exists between the absence of the CTR3-associated Ty2 element and CTR3 mRNA expression. We have also examined several $S$. cerevisiae strains isolated from human lung, peritoneal fluid, bile, and blood (McCusker et al. 1994) and found no Ty2 element associated with the CTR3 locus, suggesting that these clinically isolated strains express the CTR3 gene (data not shown).

\section{Expression and subcellular location of Ctr $3 p$}

The Ctrlp is a plasma membrane-associated protein with limited sequence homology to prokaryotic $\mathrm{Cu}$ homeostasis proteins (Cha and Cooksey 1991; Odermatt et al. 1993). Ctr3p restores high-affinity $\mathrm{Cu}$ transport to ctr1 $1 \Delta$ strains, yet exhibits no strong sequence homology to Ctrlp. Therefore, to begin to characterize Ctr3p, we carried out experiments to determine the Ctr3p subcellular location. The Ctr3 protein was tagged at the carboxyl terminus with three tandem repeats of the influenza virus hemagglutinin epitope (HA) by site-directed mutagenesis of the $C T R 3^{\mathrm{s}}$ gene. S. cerevisiae strain SKY1 (ctr1 $\Delta$ ) transformed with a single-copy plasmid carrying the CTR3-HA gene grew on YPE medium, indicating that the Ctr3-HA protein is functional in highaffinity $\mathrm{Cu}$ uptake (data not shown). This strain was grown in the absence or presence of exogenous $\mathrm{Cu}$ and equal amounts of protein extract subjected to SDS-PAGE and Western blotting using the anti-HA mAb 12CA5 (Niman et al. 1983; Kolodziej and Young 1991). This analysis demonstrated the presence of a major polypeptide species slightly larger than $30 \mathrm{kD}$, consistent with the expected size of Ctr3-HAp as predicted by the sequence of the ORF (Fig. 5A). A second higher molecular weight polypeptide species of low abundance was observed in these extracts that may represent a multimeric or posttranslationally modified form of the polypeptide, or incompletely denatured Ctr3-HA polypeptide. Consistent with the regulation of CTR3 mRNA levels, the Ctr3-HA protein levels were dramatically reduced in cells grown for $1.5 \mathrm{hr}$ in the presence of $100 \mu \mathrm{M} \mathrm{CuSO}_{4}$ (Fig. 5A).

The primary structure of Ctr3p predicts that this protein contains two potential membrane-spanning regions (Fig. 2A). To ascertain whether Ctr3p is a membrane protein, Ctr3-HAp was expressed on a single-copy plasmid in a yeast strain (RSY620) deficient in vacuolar proteases because of a pep4 gene disruption. Extracts prepared from this strain were fractionated by centrifugation and analyzed by Western blotting (Fig. 5B). The majority of epitope-tagged Ctr3 protein was detected in the $10,000 \mathrm{~g}$ pellet $\left(\mathrm{P}_{10}\right)$ and the $105,000 \mathrm{~g}$ pellet $\left(\mathrm{P}_{100}\right)$ with smaller amounts in the crude $450 \mathrm{~g}$ pellet $\left(\mathrm{P}_{0.5}\right)$. No Ctr3-HAp was detected in the soluble fraction from the $105,000 \mathrm{~g}$ spin $\left(S_{100}\right)$. An identical fractionation was carried out in the presence of $0.1 \mathrm{M} \mathrm{Na}_{2} \mathrm{CO}_{3}(\mathrm{pH} \mathrm{11)}$, which linearizes membrane structures releasing nonintegral membrane proteins into the soluble fraction (Fujiki et al. 1982). Kar2 protein, an endoplasmic reticulum (ER) lumen protein that is undetectable in the $S_{100}$ fraction in the absence of $\mathrm{Na}_{2} \mathrm{CO}_{3}$, was released into the $\mathrm{S}_{100}$ fraction by the $\mathrm{Na}_{2} \mathrm{CO}_{3}$ treatment (Fig. 5B). However, no CTR3HAp was observed in the $\mathrm{Na}_{2} \mathrm{CO}_{3} \mathrm{~S}_{100}$ fraction, demonstrating that $\mathrm{Ctr} 3 \mathrm{p}$ is an integral membrane protein (Fig. 5B).

To investigate the cellular location of Ctr3-HAp, indirect immunofluorescence microscopy was performed using the mAb $12 \mathrm{CA} 5$ to detect HA-tagged Ctr3p and anti-myc monoclonal antibody to detect myc-tagged Ctrlp. These experiments were performed in strain SLY4, which expresses both the CTR1 and CTR3 genes,
Figure 5. Ctr3p is an integral membrane protein biosynthetically regulated by $\mathrm{Cu} .|A|$ Strain SKY1, transformed with plasmid pCTR3-C-HA/315, was grown to early log phase in SC - leucine media. Cells were harvested, resuspended in YPD media, and incubated at $30^{\circ} \mathrm{C}$ for $1 \mathrm{hr}$. $\mathrm{Cu}(100 \mu \mathrm{m})$ was added to half the culture, and the Cu-treated $1+\mid$ and control $(-\mid)$ cultures were incubated for $1.5 \mathrm{hr}$ at $30^{\circ} \mathrm{C}, 300 \mathrm{rpm}$. Protein extract $(30 \mu \mathrm{g})$ from each culture was fractionated on a $15 \%$ SDS-polyacrylamide gel and transferred to nitrocellulose for Western blot analysis with 12CA5 anti-HA antibody. Immunoreactive protein was detected by chemiluminescence and exposure to Hyperfilm. Molecular mass markers are indicated at right, and the position of Ctr3-HAp is indicated with an arrow. (B) Strain RSY620 (pep4 $\Delta$ ) was transformed with pCTR3-C-HA/315 and grown in a similar manner to that described for SKY1 above, but without the addition of $\mathrm{Cu}$. Cell extracts, prepared in the absence or presence of $0.1 \mathrm{M} \mathrm{Na}_{2} \mathrm{CO}_{3}$ at $\mathrm{pH} 11$, were fractionated by centrifugation to give three pellets, $\mathrm{P}_{0.5}(450 \mathrm{~g}), \mathrm{P}_{10}(10,000 \mathrm{~g})$, and $\mathrm{P}_{100}(105,000 \mathrm{~g})$, and a $105,000 \mathrm{~g}$ supernatant $\mathrm{S}_{100}$. Protein $(30 \mu \mathrm{g})$ from each fraction was separated on a $12 \%$ SDS-polyacrylamide gel and transferred to nitrocellulose for Western blot analysis of Ctr3-HAp and Kar2p using the corresponding antibodies. The positions of the Kar2 and Ctr3-HA proteins are indicated with arrows.
A

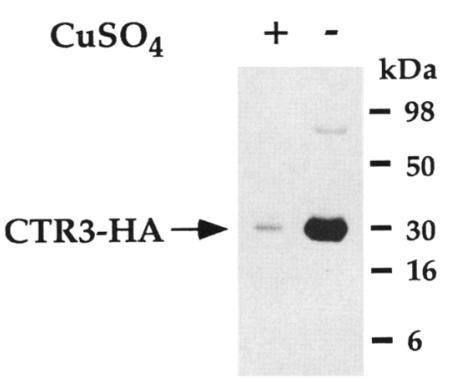

B

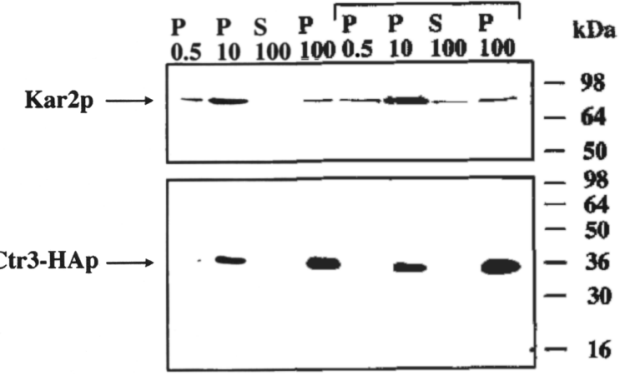


A

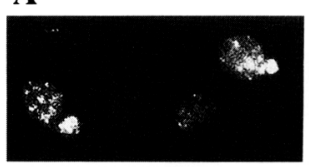

C

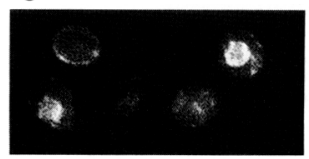

$\mathbf{E}$

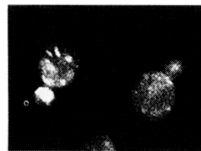

$\mathbf{F}$

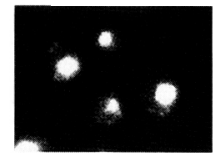

B

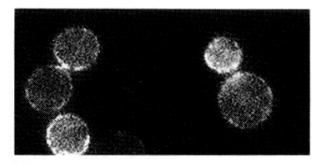

D

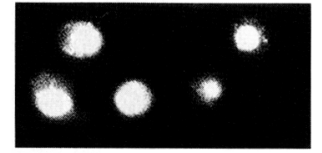

G

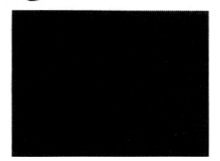

Figure 6. Ctr3-HAp is an intracellular protein associated with the vesicular structures. Strain SLY4 (CTR1 CTR3) transformed with plasmid pCTR3-C-HA/315 or p352-myc (CTR1-myc) was grown overnight in $\mathrm{SC}$ - selective media and switched to YPD media for $3 \mathrm{hr}$ to induce gene expression. Fixed cells were incubated with anti-HA monoclonal antibody to detect Ctr3HAp $(A)$ and anti-Kar2p antisera $(C)$ or anti-myc monoclonal antibody to detect Ctrl-mycp $(B)$. FITC or rhodamine red-conjugated secondary antibodies was used to visualize the primary antibody-protein complexes. DAPI staining visualized nuclear and mitochondrial DNA $(D)$ The same cell fields are shown in $A, C$, and $D .\{E)$ Ctr3-HAp location in strain SKYl $(c t r 1 \Delta) ;(F)$ DAPI staining in the same field of cells as in $E .(G)$ Field of five SLY4 cells transformed with control plasmid pRS315 and treated identically to cells in $A$.

transformed with either pCTR3-C-HA/315 or p352myc (for Ctr1-mycp expression). The intracellular punctate pattern of Ctr3-HAp (Fig. 6A), combined with the biochemical fractionation data, suggests that Ctr3-HAp is associated with vesicular components of the cell. Focusing through the planes of the cell confirmed the intracellular, as opposed to peripheral, location of Ctr3HAp. In cells with small anuclear buds there was an enrichment of Ctr3-HAp in the bud and at the bud interface with the mother cells. This is a common feature of proteins localized to the ER, Golgi, and secretory vesicles (Preuss et al. 1992). We did not observe Ctr3-HAp at the plasma membrane, suggesting that unlike Ctrlp, which has been shown previously to be located at the plasma membrane (Fig. 6B; Dancis et al. 1994b), Ctr3p is not concentrated at this site. Double immunofluorescence labeling carried out with antibodies to Kar2p, which is located in the ER, and Kex2p, which is a transGolgi protein (Rose et al. 1989; Redding et al. 1991), indicated that Crt3-HAp is not concentrated solely in either of these compartments, though there is partial overlap of some of the Ctr3p punctate spots with the Kar2p protein (Fig. 6, cf. A and C; data not shown). These same experiments, carried out in the ctr1 deletion strain SKY1, showed similar Ctr3-HAp punctate staining, indicating that $\mathrm{Ctr} 1 \mathrm{p}$ does not influence $\mathrm{Ctr} 3 \mathrm{p}$ localization (Fig. 6E). In addition, DAPI staining (Fig. 6D,F) showed that Ctr3-HAp is not enriched in the nucleus or mito- chondria. Together, the dispersed punctate pattern of intracellular staining, the integral membrane nature of $\mathrm{Ctr} 3 \mathrm{p}$, and Ctr3p primary sequence features (see Discussion) are suggestive of a protein that is associated with the yeast secretory/vesicular system.

\section{Ctr1p and $C t r 3 p$ function requires $\mathrm{Cu}(I I)$ reduction}

Although Ctrlp and Ctr3p both function in high-affinity $\mathrm{Cu}$ uptake, these proteins are structurally dissimilar and are concentrated in distinct subcellular locations. To determine whether these two proteins may have similar requirements for high-affinity $\mathrm{Cu}$ uptake, we tested the dependence on FRE1, encoding a cell-surface $\mathrm{Cu} / \mathrm{Fe}$ reductase, for Ctrlp and Ctr3p function in $\mathrm{Cu}$ transport. The data in Figure 7 demonstrate, as observed previously (Hassett and Kosman 1995), that Ctrlp-mediated highaffinity $\mathrm{Cu}$ transport is decreased $\sim 90 \%$ in the fre1 $\Delta$ strain as compared with the isogenic wild-type strain SEY6210. Similarly, $\sim 70 \%$ of the Ctr3p-mediated highaffinity $\mathrm{Cu}$ transport is abolished in the absence of FRE1. Therefore, the Ctrl and Ctr3 proteins require the FRE1encoded $\mathrm{Cu} / \mathrm{Fe}$ reductase for efficient high-affinity $\mathrm{Cu}$ uptake, suggesting strongly that both components are involved in the transport of reduced $\mathrm{Cu}(\mathrm{Cu} \mathrm{I})$.

\section{Contributions of Ctr1p and Ctr3p-Cu transport and cell growth}

Our results suggest that in a strain in which both the CTR1- and CTR3-Cu transport components are normally active, elimination of either system alone may not eliminate high-affinity $\mathrm{Cu}$ transport. To test this hypothesis, we created single and double deletions of the

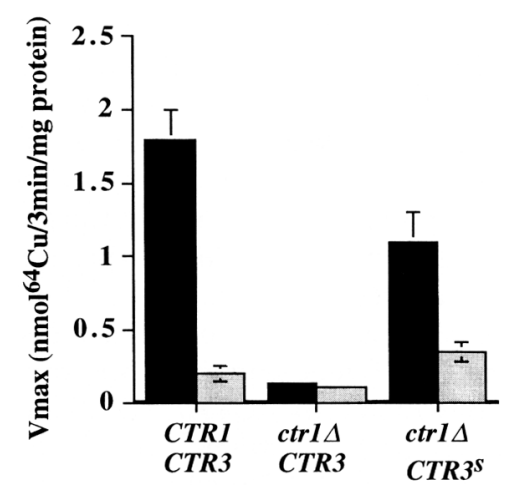

Figure 7. Ctr3p function in high-affinity $\mathrm{Cu}$ uptake requires a cellular $\mathrm{Cu}$ reductase. The FRE1 gene encoding a $\mathrm{Cu} / \mathrm{Fe}$ reductase was insertionally inactivated in the isogenic yeast strains SEY6210 (CTR1 CTR3), SKY1 (ctr1D CTR3), and SKY3 (ctr1 $1 \triangle C T R 3^{\mathrm{s}}$ ). These strains were grown in YPD to early logphase and high-affinity ${ }^{64} \mathrm{Cu}$ uptake was measured as described in Materials and methods. Solid bars indicate the ${ }^{64} \mathrm{Cu}$ uptake rate in FRE1 cells; shaded bars indicate the ${ }^{64} \mathrm{Cu}$ uptake rate in fre1 $\Delta$ cells. Results are representative of two experiments; error bars indicate the standard deviation of samples analyzed in triplicate. 
CTR1 and CTR3 genes in strain BR10, which expresses both the CTR1 the CTR3 genes because of a lack of the Ty2 element in the CTR3 promoter (Fig. 4B). As shown in Figure $8 \mathrm{~A}$, high-affinity $\mathrm{Cu}$ transport is reduced to $\sim 50 \%$ that of the parental strain by deletion of the CTR 1 gene and to $\sim 75 \%$ that of the parental strain attributable to a deletion of the CTR3 gene. This decrease in the rate of $\mathrm{Cu}$ uptake in the $c$ tr $1 \Delta$ or $c$ tr $3 \Delta$ cells did not render these strains defective for growth on YPE agar (Fig. 8A). When both the CTR 1 and CTR3 genes were insertionally inactivated, these cells failed to carry out significant levels of high-affinity $\mathrm{Cu}$ transport and, as a consequence, failed to grow on YPE agar (Fig. 8A). To assess the potential contributions of Ctrlp and Ctr3p to cell growth more quantitatively, the rate of growth in YPE medium for the isogenic parent strain (CTR1 CTR3), ctr1 $\Delta$ and ctr3 $\Delta$ strains was measured in YPE broth (Fig. 8B). Under these conditions, no significant differences in the growth rate of either of the three strains was observed. If, however, $\mathrm{Cu}$ was limited in YPE broth by the addition of the $\mathrm{Cu}$-chelator BCS, then the growth rate of the strains possessing either only Ctrlp or Ctr3p was decreased significantly as compared with the isogenic wild type expressing both proteins (Fig. $8 \mathrm{C}$ ). This was most apparent at $72 \mathrm{hr}$ when the wild-type (CTR1 CTR3) strain is at mid-log phase but the two deletion strains $\{c t r 1 \Delta$ or ctr $3 \Delta$ ) are only at the entry to log-phase. Therefore, under standard laboratory growth conditions, either Ctrlp or Ctr3p will suffice for respiratory growth; however, under copper-limiting conditions both proteins are required for maximal growth rate. These data clearly establish that both Ctrlp and Ctr3p have important physiological roles in high-affinity $\mathrm{Cu}$ transport and cell growth.

\section{Discussion}

$\mathrm{Cu}$ is an essential biochemical cofactor that is required for a wide variety of enzymatic reactions. In this work we have used classical yeast extragenic suppression approaches to identify a new gene, CTR3, involved in highaffinity $\mathrm{Cu}$ transport. In the absence of the plasma membrane-associated high-affinity $\mathrm{Cu}$ transport protein $\mathrm{Ctrl}$, yeast cells that express $\mathrm{Ctr} 3 \mathrm{p}$ suppress all of the $\mathrm{Cu}$ deficiency-based phenotypes that occur as a result of inactivation of the CTR1 gene. Furthermore, the analysis of yeast strains in which either CTR1, CTR3, or both genes have been insertionally inactivated clearly demonstrates that either CTR1- or CTR3-mediated high-affinity $\mathrm{Cu}$ transport suffices for growth under standard laboratory conditions. The inactivation of both CTR 1 and CTR 3 in such strains is required to generate all of the $\mathrm{Cu}$ deficiency phenotypes associated with a CTR1 gene deletion in a strain lacking a CTR3-encoded $\mathrm{Cu}$ transport protein (Dancis et al. 1994a,b). Both the CTR1 and CTR3 gene products have physiologically important roles in highaffinity $\mathrm{Cu}$ transport and cell growth.

It is intriguing that the yeast genome encodes two structurally unrelated proteins that function in high-af-
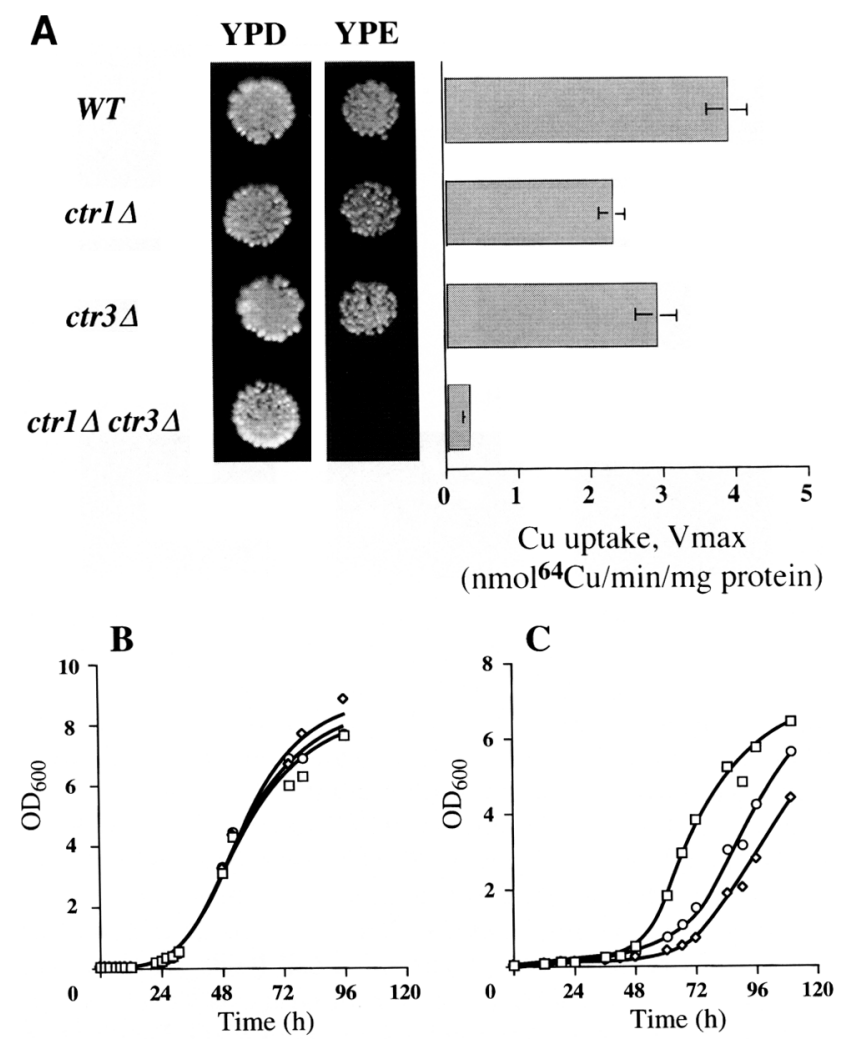

Figure 8. Both $C t r l p$ and $C t r 3 p$ have important physiological roles in high-affinity $\mathrm{Cu}$ transport and cell growth. $(A)$ Three isogenic yeast strains and one congenic strain, [BR10 (WT),

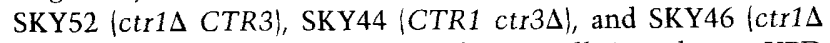
ctr $3 \Delta \|$ were spotted at a density of 2000 cells $/ 10 \mu l$ onto YPD and YPE agar media and incubated at $30^{\circ} \mathrm{C}$ for 2 and 4 days, respectively. The high-affinity ${ }^{64} \mathrm{Cu}$ uptake rate was measured in these strains, grown in YPD broth, as described in Materials and methods. The $\mathrm{Cu}$ uptake values are represented as a horizontal bar with the standard deviation indicated for triplicate measurements. Growth of strains BR10 (WT, $\square$ ), SKY52 (ctr1s CTR3, $\diamond)$, and SKY44 (CTR1 ctr3A, O) was assessed in YPE liquid cultures in the absence $(B)$ or presence $(C)$ of $100 \mu \mathrm{M}$ BCS. All cultures were started at an $\mathrm{OD}_{600}$ of 0.02 ; optical density measurements represent the mean of three independent cultures in $C$.

finity $\mathrm{Cu}$ transport. On one hand, the CTR1- and CTR3mediated $\mathrm{Cu}$ transport activities are similar in the $\mathrm{Cu}$ dependent biochemical processes they support, the requirement of both for $\mathrm{Cu}$ reductase activity for function in $\mathrm{Cu}$ transport, the membrane association of Ctrlp and $\mathrm{Ctr} 3 \mathrm{p}$, and the regulation of gene expression in response to fluctuations in cellular $\mathrm{Cu}$ status. However, these two proteins are distinct with respect to their primary sequences, subcellular distribution, and apparent functional independence, as ascertained by gene deletion studies and lack of direct interaction in coimmunoprecipitation experiments (data not shown). Subcellular fractionation experiments and indirect immunofluorescence microscopy demonstrate that $\mathrm{Ctr} 3 \mathrm{p}$ is an integral membrane protein associated with intracellular vesicu- 
lar structures. In support of these experimental data, the Ctr3p carboxyl terminus contains two structural features associated with proteins that are retained in the ER/Golgi network. First, the carboxy-terminal sequence of $\mathrm{Ctr} 3 \mathrm{p}, \mathrm{RKCCL}$, is similar to the yeast $\mathrm{ER}$ retention signal (Basic/Basic/X/X) (Nilsson et al. 1989; Jackson et al. 1990; Townsley and Pelham 1994), and our data suggest that a fraction of Ctr3p colocalizes with Kar2p, which is located in the ER. Second, Ctr3p also contains the sequence FCYEPL, which conforms to an element of the consensus $(\mathrm{Y} / \mathrm{F}|\mathrm{X} / \mathrm{Y} / \mathrm{F}| \mathrm{XX}(\mathrm{I} / \mathrm{L})$, which, in turn, has a critical role in Golgi retention for both the Kex2 protease and dipeptidyl aminopeptidase of $S$. cerevisiae (Wilcox et al. 1992; Nothwehr et al. 1993). The integral membrane nature of Ctr3p and the abundance of punctate staining that does not strictly colocalize to either the ER or transGolgi, is suggestive of a protein that might be associated with other Golgi compartments or larger secretory/endosomal vesicles as well (Franzusoff et al. 1991).

How might an integral membrane protein localized to intracellular vesicular structures function in high-affinity $\mathrm{Cu}$ transport? One possible mechanism is that $\mathrm{Ctr} 3 \mathrm{p}$ functions in an endocytic pathway of copper uptake distinct from the Ctrlp pathway. There is biochemical evidence for two $\mathrm{Cu}$ transport pathways in mammalian cells, one for unbound $\mathrm{Cu}$ and a second endocytic process for ceruloplasmin-bound $\mathrm{Cu}$, though the cellular components involved in these pathways have not been identified (Vulpe and Packman 1995). As part of an endocytic $\mathrm{Cu}$ transport pathway in yeast, $\mathrm{Ctr} 3 \mathrm{p}$ may rapidly recycle to and from the plasma membrane from intracellular vesicles. The $S$. cerevisiae Ste 6 protein has been shown to move to and from the membrane as a function of $\alpha$-factor stimulation (Kuchler et al. 1993; Kolling and Hollenberg 1994). Although we do not detect $\mathrm{Ctr} 3 \mathrm{p}$ concentrated at the plasma membrane like Ctrlp, either a very transient association or rapid protein turnover, as suggested by the $\mathrm{Cu}$-mediated down-regulation of Ctr3p (Fig. 5A), could preclude our detection of Ctr3p at the cell surface. The analysis of Ctr3p function in an end4 mutant background did not reveal any defect in $\mathrm{Cu}$ transport or cell growth (data not shown); however, this mutant does have residual endocytic transport function (Raths 1993). In both yeast and mammalian cells it is clear that there are at least two distinct pathways of endocytosis (Helenius et al. 1983; Riezman 1985). Alternatively, Ctr3p may function to release $\mathrm{Cu}$ to the cytosol from intracellular vesicles, thereby increasing the rate of endocytic $\mathrm{Cu}$ uptake. It is also possible that $\mathrm{Ctr} 3 \mathrm{p}$ has a less direct role in the same high-affinity $\mathrm{Cu}$ transport pathway as Ctrlp. Ctr3p could serve as a chaperone to facilitate the trafficking of other protein components, that might operate with Ctrlp, through the secretory network to the plasma membrane. Such specific chaperone roles have been found for Hsp47, a collagen-specific chaperone, and receptor-associated protein (RAP), a chaperone for the low-density lipoprotein (LDL) receptor-related protein (Bu et al. 1995; Nagata 1996). Consistent with our $\mathrm{Cu}$ transport measurements in a CTR1 $\operatorname{ctr} 3 \Delta$ strain, these components could be inefficiently de- livered to the plasma membrane but their delivery may be enhanced by Ctr3p. In cells lacking Ctrlp, the action of $\mathrm{Ctr} 3 \mathrm{p}$ in augmenting proper $\mathrm{Cu}$ transport complex assembly at the plasma membrane could allow a significant level of high-affinity $\mathrm{Cu}$ transport. Clearly, our data demonstrate that the expression of both Ctrlp and Ctr3p is required for the most efficient high-affinity $\mathrm{Cu}$ transport activity and for normal cell growth under conditions in which copper is required, yet limiting.

Our observation that CTR3 gene transcription in most laboratory strains examined is eliminated by an insertion of a transposable element in the CTR 3 promoter is consistent with previous observations in bacteria and yeast (Kleckner 1989; Boeke and Sandmeyer 1991). It is well established that transposable elements preferentially insert in the $5^{\prime}$-flanking regions of genes and either inactivate or modify the expression of the flanking loci (Eibel and Philippsen 1984; Boeke 1989). The yeast his4917 allele contains a spontaneously inserted Ty2 element that displaces the TATA box, thereby inhibiting HIS4 gene transcription (Roeder et al. 1980). The insertion of a Ty2 element in the CTR 3 promoter has a similar consequence and excision of the Ty2 element restores CTR3 gene expression and high-affinity $\mathrm{Cu}$ transport. The nature of the CTR3 Ty2 insertion is in agreement with the current model that Ty elements inserted with the same orientation for expression as the target gene displace the normal regulatory sequences without substituting Ty-mediated regulation (Boeke and Sandmeyer 1991).

An important ramification of the effect of Ty element insertion on gene expression involves the current yeast sequencing project. The entire yeast genome has now been sequenced. The next step in this project is the systematic deletion of ORFs coupled with phenotype screening (Wach et al. 1994). Based on our results with $C T R 3$, and previous observations of the effect of transposons on gene expression, the ORF disruption experiments must be interpreted carefully. It is quite possible that many of the phenotypic differences observed in yeast strains are caused by the presence (or absence) of the Ty class of mobile DNA elements in the genome. Inspection of the entire yeast genome sequence reveals that in strain S288C there are six Ty2 elements with $98 \%$ or greater identity with the Ty 2 at the CTR3 locus. This suggests that the expression of other genes, and consequently yeast cell phenotypes, might be altered by this class, as well as other Ty elements. Recent studies of mice with a disrupted epidermal growth factor receptor (EGFR) gene demonstrated that embryonic lethality varied in a manner dependent on the mouse genetic background (Sibilia and Wagner 1995; Threadgill et al. 1995). The nature of this genetic variation is not clear, however, it is possible that the retrotransposon-like short or long interspersed elements (SINEs and LINEs, respectively) are involved in shaping the genome of these highly inbred mouse strains (Deininger 1989; Hutchinson et al. 1989). This work, demonstrating that a Ty2 element suppresses the expression of an important $\mathrm{Cu}$ transport gene, underscores the critical role that trans- 
posable elements have in shaping genome evolution and function.

\section{Materials and methods}

Yeast strains and plasmids

Yeast strains used in this study are listed in Table 1. The ctr1::URA3 allele was constructed by deleting a $1.5-\mathrm{kb}$ DNA fragment encoding $82 \%$ of the CTR 1 ORF and $5^{\prime}$ untranslated region, and replacing it with the URA3 genetic marker. The ctr1::TRP1 allele was constructed by replacing a 0.9-kb DNA fragment encoding the 145 amino-terminal amino acids and $0.45 \mathrm{~kb}$ of the $5^{\prime}$ untranslated region with the TRP1 genetic marker. The pctr $3:$ :LEU2 disruption plasmid was constructed by ligating a BglII-LEU2 fragment, isolated from Yep13, into the BgIII site of the CTR3 gene in pCTR3/S-X/315. pctr3::LEU2 was digested with PvuII and the DNA products were transformed into yeast cells to generate the ctr3::LEU2 allele by homologous recombination. The $\operatorname{ctr} 3^{s}:: U R A 3$ and $c t r 3:: T R P 1$ alleles were constructed by integration of the respective genetic markers into the BglII site of the CTR 3 gene. These disruptions rendered the CTR1 and CTR3 genes nonfunctional as assessed by the absence of growth on YPE media. Strain SKY46 (ctr1::URA3 ctr3::TRP1) was obtained by sporulation of a diploid derived from a cross of SKY1 and SKY44. The fre 1::LEU2 allele was constructed by deletion of 800 bp of FRE1 DNA and replacement with the LEU2 gene as described (Dancis et al. 1992). The allele status of each of these loci in all strains generated in this study was verified using Southern blotting and diagnostic PCR. The CTR3 allele in strain BR10 lacks the Ty2 element and sequence analysis of the CTR 3 promoter from this strain shows no evidence for prior Ty2 insertion (Fig. 2B).

\section{Growth media and genetic methods}

Yeast cells were grown, unless otherwise stated, in YPD $(1 \%$ yeast extract, $2 \%$ bactopeptone, and $2 \%$ dextrose),YPE, or SC (synthetic complete), which are described elsewhere in detail (Sherman et al. 1986). Yeast cells were transformed with DNA using lithium acetate (Ito et al. 1983) and plasmids were rescued by lysis of yeast spheroplasts and enriching for plasmid DNA on a Qiagen-tip 100 (Qiagen, Inc., Chatsworth, CA). Mating of yeast cells, EMS mutagenesis, sporulation of diploids, and tetrad dissection used standard methods (Sherman et al. 1986). All DNA and RNA manipulation and analyses were carried out as described previously (Ausubel et al. 1987).

\section{Ctr $3 p$ epitope tagging}

A NotI site was generated in $\mathrm{pCTR} 3 / \mathrm{H}-\mathrm{X} / \mathrm{SK}$ immediately after the CTR3 carboxy-terminal leucine, using a Muta-gene kit (Bio$\mathrm{Rad}$ ) for in-frame insertion of the HA tag. This plasmid expresses a functional HA-tagged $\mathrm{Ctr} 3 \mathrm{p}$ protein as assessed by complementation of a $\operatorname{ctr} 1 \Delta$ allele in SKY1. Plasmid 352-myc, which encodes the myc-tagged Ctrl protein, was a generous gift from Andrew Dancis (National Institutes of Health, Bethesda, $\mathrm{MD}$ ).

\section{$\mathrm{Cu}$ and Fe uptake}

Yeast cells were grown to early log phase in YPD media. The cells were harvested by centrifugation and washed twice in metal uptake/metal reductase (UR) buffer [0.2 M MES (4-morpholinepropanesulfonic acid) containing $5 \%(\mathrm{wt} / \mathrm{vol})$ glucose and citrate $(20 \mathrm{~mm})$ at $\mathrm{pH} 6.0)$. The cells were resuspended in UR buffer at the original density of $1 \times 10^{7}$ to $2 \times 10^{7}$ cells $/ \mathrm{ml}$ or $A_{660}=1.0$. Metal radionucleotide [plus nonradioactive metal ion as needed for a given (metal) total ) was equilibrated in $1 \mathrm{ml}$ of UR buffer containing, unless noted, $1 \mathrm{~mm}$ dihydroascorbic acid. The equilibrated metal solution was added to $6 \mathrm{ml}$ of yeast cells and samples were removed at 2 and $5 \mathrm{~min}$, for ${ }^{64} \mathrm{Cu}$ uptake, or at 20 $\mathrm{min}$, for ${ }^{59} \mathrm{Fe}$ uptake. Cell samples were quenched in $5 \mathrm{ml}$ of ice-cold $10 \mathrm{~mm}$ EDTA in $0.1 \mathrm{M}$ Tris succinate at $\mathrm{pH} 6.0$, and washed by filtration through nitrocellulose filters $10.45 \mu \mathrm{m}$ Gelman) with a total of $20 \mathrm{ml}$ of quench solution. The filters were

Table 1. S. cerevisiae strains used in this work

\begin{tabular}{|c|c|c|}
\hline Strain & Genotype & Source \\
\hline SEY6210 & MATa ura3-52 leu2-3,-112 his3-4200 trp1-4901 lys2-801 suc2- $\Delta 9$ & Scott Emr \\
\hline SKY1 & MATa ura3-52 leu2-3,-112 his3-4200 trp1-4901 lys2-801 suc2- $\Delta 9$ ctr1::URA3 & this study \\
\hline W303-1A & MATa SUC2 ade2-1 can1-100 his3-11,115 leu2-3,112 trp1-1 ura3-1 & $\begin{array}{l}\text { Yeast Genetic } \\
\text { Stock Center }\end{array}$ \\
\hline SKY2 & MATa SUC2 ade2-1 can1-100 his3-11,115 leu2-3,112 trp1-1 ura3-1 ctr1::URA3 & this study \\
\hline SKY3 & 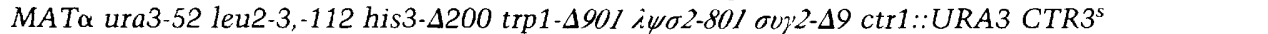 & this study \\
\hline SKY12 & 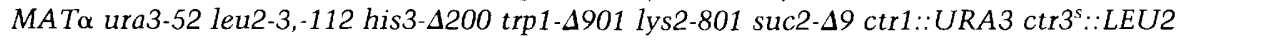 & this study \\
\hline $\mathrm{S} 288 \mathrm{C}$ & MAT $\alpha$ SUC2 mal mel gal2 CUP1 & $\begin{array}{l}\text { Yeast Genetic } \\
\text { Stock Center }\end{array}$ \\
\hline BR10 & MATa gal1 trpl-1 his3 ade CUP1 & Brian Rymond \\
\hline SKY44 & MATa gal1 trpl-1 his3 ade CUP1 ctr3::TRP1 & this study \\
\hline SKY46 & MATa $\operatorname{ctr} 1:: U R A 3$ ctr3::TRP1 lys2-801 his3 (spore clone from SKY1 $\times$ SKY 44 cross) & this study \\
\hline SKY51 & 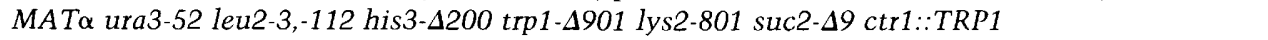 & this study \\
\hline SKY52 & MATa gal1 trp1-1 his3 ade CUP1 ctr1::TRP1 & this study \\
\hline SKY61 & 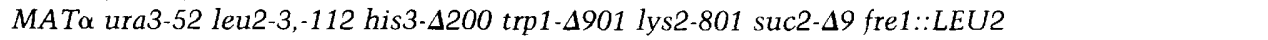 & this study \\
\hline SKY62 & 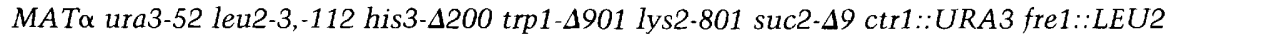 & this study \\
\hline SKY63 & 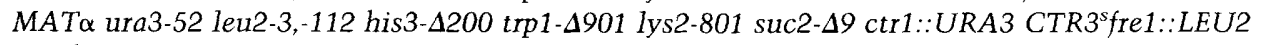 & this study \\
\hline Y55 & HO lys5 & John McCusker \\
\hline DTY14 & MATa thr4 & Gary Fabian \\
\hline SLY4 & MATa gal1 trp1-1 his3 ade CUP1-10 leu2::hisG ura3::kan ${ }^{x}$ & this study \\
\hline RSY620 & MATa ade2 leu2-3,-112 his3 trp1 ura3 pep4::TRP1 & Randy Schekman \\
\hline
\end{tabular}


counted in an LKB CompuGamma counter that corrected the values for isotope decay. Data for ${ }^{64} \mathrm{Cu}$ uptake was derived from the difference between the 2 - and 5 -min counts. ${ }^{59} \mathrm{Fe}$ uptake was taken as the value for the 20 -min sample directly, because unlike ${ }^{64} \mathrm{Cu}$ uptake, there is no nonspecifically absorbed cell associated radionucleotide at $t=15 \mathrm{sec}$ (Hassett and Kosman 1995). Kinetic constants for ${ }^{64} \mathrm{Cu}$ uptake were obtained by direct nonlinear fit of the data to the Michaelis-Menten equation using the program UltraFit (Biosoft). ${ }^{59} \mathrm{Fe}$ uptake was performed under $V_{\text {max }} / K_{\mathrm{m}}$ conditions $(0.2 \mathrm{mM})$ and the results given as the velocity at this Fe concentration (Eide et al. 1992).

\section{Protein and enzyme assays}

Protein concentrations in cell extracts were determined using the Pierce BCA kit following the manufacturer's instructions. Total superoxide dismutase and $\mathrm{Cu}, \mathrm{Zn}$ SOD activities were determined colormetrically, by measuring the inhibition of nitrite formation from hydroxylamine- $\mathrm{O}$-sulfonic acid in the absence or presence of KCN (Oyanagui 1984). Cupric and ferric reductase activities were determined by the change in absorbance attributable to formation of $\mathrm{Cu}(\mathrm{I})$ with bathocuproine disulfonate and $\mathrm{Fe}(\mathrm{II})$ with bathophenanthroline disulfonate (Lesuisse and Labbe 1989; Hassett and Kosman 1995). Ctr3-HAp and Kar2p detection was carried out by Western blotting as described (Ausubel et al. 1987).

\section{Cellular fractionation}

The pep4 delete strain RSY620 transformed with pCTR3-C$\mathrm{HA} / 315$ was grown in $\mathrm{SC}$ - leucine overnight, subcultured into YPD, and grown for a further $2 \mathrm{hr}$ at $30^{\circ} \mathrm{C}$ to induce Ctr3-HAp synthesis. Spheroplasts were generated from the harvested cells and cell extracts were prepared in the absence or presence of $0.1 \mathrm{M} \mathrm{Na} \mathrm{NaO}_{3}$ at $\mathrm{pH} 11$ (Fujiki et al. 1982). The extracts were centrifuged to obtain three pellet fractions of $450 \mathrm{~g}, 10,000 \mathrm{~g}$, and $105,000 g$, plus a $100,000 g$ supernatant, $\mathrm{P}_{0.5}, \mathrm{P}_{10}, \mathrm{P}_{100}$, and $\mathrm{S}_{100}$ respectively. The presence of Ctr3-HAp and Kar2p in these fractions was assessed by Western blotting.

\section{Indirect double-labeling immunofluorescence}

These methods were based on those described by Franzusoff et al. (1991). For localization of Ctr3-HAp and Kar2p, yeast strain SLY4 or SKY1 transformed with single-copy pCTR3-C-HA/ 315 or control vector pRS315 was grown overnight in SC-leu media. Cells were harvested, resuspended in YPD to an $\mathrm{OD}_{600}=1.5$ and incubated at $30^{\circ} \mathrm{C}$ for $3 \mathrm{hr}$ to induce Ctr3-HAp expression under conditions of low $\mathrm{Cu}$ availability. Formaldehyde $(4.0 \%$ final concentration) and potassium phosphate buffer at $\mathrm{pH} 6.5(0.1 \mathrm{M}$ final concentration) were added directly to the growing cells. After $40 \mathrm{~min}$, the fixed cells were harvested and washed with $0.1 \mathrm{M}$ potassium phosphate at $\mathrm{pH} 6.5$, containing $1.2 \mathrm{M}$ sorbitol (KPS). Spheroplasts were formed by incubating the cells with $1 \% \beta$-mercaptoethanol and $0.25 \mathrm{mg} / \mathrm{ml}$ of $\mathrm{Zy}$ molyase T100 in KPS for $40 \mathrm{~min}$ at $30^{\circ} \mathrm{C}$. Spheroplasts were washed in KPS and adsorbed to polylysine-coated multiwell slides. Cells were incubated with anti-HA antibody (12CA5) and the anti-Kar2p antibody (a generous gift from R. Fuller, University of Michigan Medical School, Ann Arbor) diluted 1: 300 and $1: 100$, respectively, in PBST containing $10 \mathrm{mg} / \mathrm{ml}$ of BSA (PBST-B). All primary and secondary antibodies, except anti-Kar2p, were presorbed against yeast spheroplasts transformed with control vectors. After an overnight incubation at $4^{\circ} \mathrm{C}$, cells were washed with PBST and incubated for $2 \mathrm{hr}$ with the appropriate secondary antibodies, goat-antimouse IgG- and
IgM-conjugated fluorescein (BMB), and/or anti-rabbit IgG- conjugated rhodamine (BMB) diluted 1:500 in PBST-B. Cells were then washed in mounting solution containing DAPI 14,6-diamidino-2-phenyl-indole), and phenylamine diamine was added to each well. To localize Ctrl-mycp, SLY4 was transformed with p352-myc (a generous gift from Andrew Dancis, National Institutes of Health, Bethesda, MD). The transformed cells were grown overnight in SC-uracil, and then treated identically to those described above, except that anti-myc antibodies were used. Cells were observed using a Zeiss Axioskop photomicroscope with filters for observing fluorescein, rhodamine, and DAPI fluorescence. Fields of cells were photographed with Kodak TMAX 400 print film pushed to ASA 1600 in development. The negatives were digitized to CD-ROM and optimized for contrast and sharpness using Adobe Photoshop software.

\section{Acknowledgments}

We are grateful to Drs. Robert Fuller, David Friedman, Mark Szczypka, Jason Brickner, and members of the Thiele laboratory for critical comments on the manuscript. We thank Drs. John McCusker, Andrew Dancis, Randy Schekman, and Scott Emr for yeast strains and plasmids used in this work, and Dr. Robert Fuller for the Kex2p antibody. We thank Richard Hassett for his excellent technical assistance in metal uptake and metal reductase assays, and Chen Kuang and Annette Romeo for technical assistance. We gratefully acknowledge Dr. Karlheinz Kampfenkel for providing data before publication. This work was supported by grants from the National Institutes of Health (NIH) (RO1 GM41840 to D.J.T. and RO1 GM46787 to D.J.K.). S.A.B.K. was supported by National Research Service Award F32 GM 15662-01 from the NIH, General Medical Sciences. S.L. is a recipient of a postdoctoral fellowship from the Fonds de la Recherche en Santé du Québec (F.R.S.Q.). D.J.T. is a Burroughs Wellcome Toxicology Scholar.

The publication costs of this article were defrayed in part by payment of page charges. This article must therefore be hereby marked "advertisement" in accordance with 18 USC section 1734 solely to indicate this fact.

\section{References}

Askwith, C., D. Eide, A. Van Ho, P.S. Bernard, L. Li, S. DavisKaplan, D.M. Sipe, and J. Kaplan. 1994. The FET3 gene of $S$. cerevisiae encodes a multicopper oxidase required for ferrous iron uptake. Cell 76: 403-410.

Ausubel, F.M., R. Brent, R.E. Kingston, D.D. Moore, J.G. Seidman, J.A. Smith, and K. Struhl, ed. 1987. Current protocols in molecular biology. John Wiley \& Sons, NY, NY.

Boeke, J.D. 1989. Transposable elements in Saccharomyces cerevisiae. In Mobile DNA (ed. D.E. Berg and M.M. Howe), pp. 335-374. American Society for Microbiology, Washington DC.

Boeke, J.D. and S.B. Sandmeyer. 1991. Yeast transposable elements. In The molecular and cellular biology of the yeast Saccharomyces (ed. J.R. Broach, J.R. Pringle, and E.W. Jones), pp. 193-262. Cold Spring Harbor Laboratory Press, Cold Spring Harbor, NY.

Bu, G., H.J. Geuze, G.J. Strous, and A. L. Schwartz. 1995. 39 kDa receptor-associated protein is an ER residient protein and a molecular chaperone for LDL receptor-related protein. EMBO I. 14: 2269-2280.

Catterall, W.A. 1995. Structure and function of voltage-gated ion channels. Annu. Rev. Biochem. 64: 493-531.

Cha, J. and D.A. Cooksey. 1991. Copper resistance in 
Pseudomonas syringae mediated by periplasmic and outer membrane proteins. Proc. Natl. Acad. Sci. 88: 8915-8919.

Culotta, V.C., W.R. Howard, and X.F. Liu. 1994. CRS5 encodes a metallothionein-like protein in Saccharomyces cerevisiae. J. Biol. Chem. 269: 25295-25302.

Dancis, A., D.G. Roman, G.J. Anderson, A.G. Hinnebusch, and R.D. Klausner. 1992. Ferric reductase of Saccharomyces cerevisiae: Molecular charcacterization, role in iron uptake, and transcriptional control by iron. Proc. Natl. Acad. Sci. 89: 3869-3873.

Dancis, A., D. Haile, D.S. Yaun, and R.D. Klausner. 1994a. The Saccharomyces cerevisiae copper transport protein (Ctrlp). J. Biol. Chem. 269: 25660-25667.

Dancis, A., D.S. Yuan, D. Haile, C. Askwith, D. Eide, C. Moehle, J. Kaplan, and R.D. Klausner. 1994b. Molecular characterization of a copper transport protein in $S$. cerevisiae: An unexpected role for copper in iron transport. Cell 76: 393-402.

De Silva, D.M., C.C. Askwith, D. Eide, and D. Kaplan. 1995. The FET3 gene product required for high-affinity iron transport in yeast is a cell surface ferroxidase. $I$. Biol. Chem. 270: 1098-1101.

Deininger, P.L. 1989. SINEs: Short interspersed repeated DNA elements in higher eukaryotes. In Mobile DNA (ed. D.E. Berg and M.M. Howel, pp. 619-636. American Society for Microbiology, Washington, D.C.

Eibel, H. and P. Philippsen. 1984. Preferential integration of yeast transposable element Ty into a promoter region. $\mathrm{Na}$ ture 307: 386-388.

Eide, D., S. Davis-Kaplan, I. Jordan, D. Sipe, and J. Kaplan. 1992. Regulation of iron uptake in Saccharomyces cerevisiae. The ferrireductase and Fe(II) transporter are regulated independently. I. Biol. Chem. 267: 20774-20781.

Franzusoff, A., J. Rothblatt, and R. Schekman. 1991. Analysis of polypeptide transit through yeast secretory pathway. Methods Enzymol. 194: 662-674.

Fujiki, F., A.L. Hubbard, S. Fowler, and P.B. Lazarow. 1982. Isolation of intracellular membranes by means of sodium carbonate treatment: Application of endoplasmic reticulum. I. Cell. Biol. 93: 97-102.

Georgatsou, E. and D. Alexandraki. 1994. Two distinctly regulated genes are required for ferric reduction, the first step of iron uptake in Saccharomyces cerevisiae. Mol. Cell. Biol. 14: 3065-3073.

Hahn, S., S. Buratowski, P.A. Sharp, and L. Guarente. 1989. Yeast TATA-binding protein TFIID binds to TATA elements with both consensus and nonconsensus DNA sequences. Proc. Natl. Acad. Sci. 86: 5718-5722.

Halliwell, B. and J.M.C. Gutteridge. 1984. Oxygen toxicity, oxygen radicals, transition metals and disease. Biochem. $I$. 219: $1-14$.

Hassett, R. and D.J. Kosman. 1995. Evidence for Cu(II) reduction as a component of copper uptake by Saccharomyces cerevisiae. J. Biol. Chem. 270: 128-134.

Helenius, A., D. Mellman, D. Wall, and A. Hubbard. 1983. Endosomes. Trends Biochem. Sci. 8: 245-250.

Hofmann, K. and W. Stoffel. 1993. TMbase-A database of membrane spanning proteins segments. Biol. Chem. HoppeSeyler 347: 166

Hutchinson III, C.A., S.C. Hardies, D.D. Loeb, W.R. Shehee, and M.H. Edgell. 1989. LINEs and related retroposons: Long interspersed repeated sequences in the eukaryotic genome. In Mobile DNA (ed. D.E. Berg and M.M. Howe), pp. 593-618. American Society for Microbiology, Washington, DC.

Ito, H., Y. Fukada, K. Murata, and A. Kimura. 1983. Transformation of intact yeast cells treated with alkalis cations. $J$.
Bacteriol 153: 163-168.

Jackson, M.R., T. Nilsson, and P.A. Peterson. 1990. Identification of a consensus motif for retention of transmembrane proteins in the endoplasmic reticulum. $E M B O J .9: 3153-$ 3162.

Kampfenkel, K., S. Kushnir, E. Babiychuk, D. Inze, and M. Van Montagu. 1995. Molecular characterization of a putative $\mathrm{Ar}$ abidopsis thaliana copper transporter and its yeast homologue. J. Biol. Chem. 270: 28479-28486.

Kleckner, N. 1989. Transposon Tn10. In Mobile DNA (ed. D.E. Berg and M.M. Howel, pp. 227-268. American Society for Microbiology, Washington, DC.

Kolling, R. and C.P. Hollenberg. 1994. The ABC-transporter Ste6 accumulates in the plasma membrane in a ubiquitinated form in endocytosis mutants. EMBO /. 13: 3261-3271.

Kolodziej, P.A. and R.A. Young. 1991. Epitope tagging and protein surveillance. Methods Enzymol. 194: 508-519.

Kuchler, K., H.G. Dohlman, and J. Thorner. 1993. The a-factor transporter (STE6 gene product) and cell polarity in the yeast Saccharomyces cerevisiae. J. Cell. Biol. 120: 1203-1215.

Lesuisse, E. and P. Labbe. 1989. Reductive and non-reductive mechanisms of iron assimilation by the yeast Saccharomyces cerevisiae. J. Gen. Microbiol. 135: 257-263.

Linder, M.C. 1991. Biochemistry of copper. Plenum Press, New York, NY.

McCusker, J.H., K.V. Clemons, D.A. Stevens, and R.W. Davis. 1994. Genetic characterization of pathogenic Saccharomyces cerevisiae isolates. Genetics 136: 1261-1269.

Mortimer, R.K. and J.R. Johnston. 1986. Genealogy of principal strains of the yeast genetic stock center. Genetics 113: 3543.

Nagata, K. 1996. Hsp47: A collagen-specific molecular chaperone. Trends Biochem. Sci. 21: 23-26.

Nilsson, T., M. Jackson, and P.A. Peterson. 1989. Short cytoplasmic sequences serve as retention signals for transmembrane proteins in the endoplasmic reticulum. Cell 58: 707718.

Niman, H.L., R.A. Houghten, L.E. Walker, R.A. Reisfeld, I.A. Wilson, J.M. Hogle, and R.A. Lerner. 1983. Generation of protein-reactive antibodies by short peptides is an event of high frequency: Implications for the structural basis of immune recognition. Proc. Natl. Acad. Sci. 80: 4949-4953.

Nothwehr, S.F., C.J. Roberts, and T.H. Stevens. 1993. Membrane protein retention in the yeast Golgi apparatus: Dipeptidyl aminopeptidase $\mathrm{A}$ is retained by a cytoplasmic signal containing aromatic residues. J. Cell. Biol. 121: 1197-1209.

Odermatt, A., H. Suter, R. Krapt, and M. Solioz. 1993. Primary structure of two P-type ATPases involved in copper homeostasis in Enterococcus hirae. I. Biol. Chem. 268: 1277512779.

Oyanagui, Y. 1984. Reevaluation of assay methods and establishment of kit for superoxide dismutase activity. Anal. Biochem. 142: 290-296.

Preuss, D., J. Mulholland, A. Franzusoff, N. Segev, and D. Botstein. 1992. Characterization of the Saccharomyces Golgi complex through the cell cycle by immunoelectron microscopy. Mol. Biol. Cell 3: 789-803.

Raths, S., J. Rohrer, F. Crausaz, and H. Riezman. 1993. end3 and end4: Two mutants defective in receptor-mediated and fluid-phase endocytosis in Saccharomyces cerevisiae. I. Cell Biol. 120: 55-65.

Redding, K., C. Holcomb, and R.S. Fuller. 1991. Immunolocalization of Kex2 protease identifies a putative late Golgi compartment in the yeast Saccharomyces cerevisiae. I. Cell. Biol. 113: $527-538$.

Riezman, H. 1985. Endocytosis in yeast: Several of the yeast 
secretory mutants are defective in endocytosis. Cell 40: 1001-1009.

Roeder, G.S., P.J. Farabaugh, D.T. Chaleff, and G.R. Fink. 1980. The origins of gene instability in yeast. Science 209: 13751380.

Roeder, G.S. and G.R. Fink. 1983. Transposable elements in yeast. In Mobile genetic elements (ed. J.A. Shapiro), pp. 300328. Academic Press, New York, NY.

Rose, M.D., L.M. Misra, and J.P. Vogel. 1989. KAR2, a karyogamy gene, is the yeast homolog of the mammalian $\mathrm{BiP} /$ GRP78 gene. Cell 57: 1211-1221.

Sherman, F., G.R. Fink, and J.B. Hicks. 1986. Methods in yeast genetics. Cold Spring Harbor Laboratory, Cold Spring Harbor, NY.

Sibilia, M. and E.F. Wagner. 1995. Strain-dependent epithelial defects in mice lacking the EGF receptor. Science 269: 234238.

Sikorski, R.S. and P. Hieter. 1989. A system of shuttle vectors and yeast host strains designed for efficient manipulations of DNA in Saccharomyces cerevisiae. Genetics 122: 19-27.

Stadtman, E.R. and C.N. Oliver. 1991. Metal-catalysed oxidation of proteins. J. Biol. Chem. 266: 2005-2008.

Stearman, R., D.S. Yuan, Y. Yamaguchi-Iwai, R.D. Klausner, and A. Dancis. 1996. A permease-oxidase complex involved in high-affinity uptake in yeast. Science 271: 1552-1557.

Threadgill, D.W., A.A. Dlugosz, L.A. Hansen, T. Tennenbaum, U. Lichti, D. Yee, C. LaMantia, T. Mourton, K. Herrup, R.C. Harris, J.A. Barnard, S.H. Yuspa, R.J. Coffey, and T. Magnuson. 1995. Targeted disruption of mouse EGF receptor: Effect of genetic background on mutant phenotype. Science 269: 230-234.

Townsley, F.M. and H.R. Pelham. 1994. The KKXX signal mediates retrieval of membrane proteins from the Golgi to the ER in yeast. Eur. I. Cell. Biol. 64: 211-216.

Vulpe, C.D. and S. Packman. 1995. Cellular copper transport. Annu. Rev. Nutr. 15: 293-322.

Wach, A., A. Brachat, R. Pohlmann, and P. Philippsen. 1994. New heterologous modules for classical or PCR-based gene disruptions in Saccharomyces cerevisiae. Yeast 10: 17931808.

Wilcox, C.A., K. Redding, R. Wright, and R. S. Fuller. 1992. Mutation of a tyrosine localization signal in the cytosolic tail of yeast Kex 2 protease disrupts Golgi retention and results in default transport to the vacuole. Mol. Biol. Cell. 3: 1353-1371.

Winge, D.R., K.B. Nielson, W.R. Gray, and D.H. Hamer. 1985. Yeast Metallothionien: Sequence and metal binding properties. J. Biol. Chem. 260: 14464-14470.

Zhu, Z., M.S. Szczypka, and D.J. Thiele. 1995. Transcriptional regulation and function of yeast metallothionein genes. In Genetic response to metals (ed. B. Sarkar), pp. 379-395. Marcel Dekker, New York, NY. 


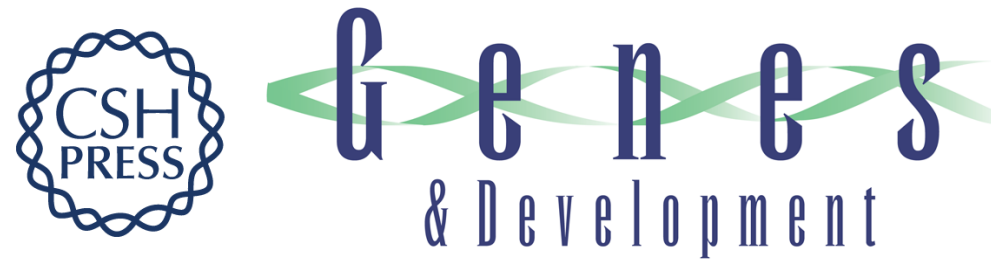

\section{A widespread transposable element masks expression of a yeast copper transport gene.}

S A Knight, S Labbé, L F Kwon, et al.

Genes Dev. 1996, 10:

Access the most recent version at doi:10.1101/gad.10.15.1917

References This article cites 50 articles, 30 of which can be accessed free at:

http://genesdev.cshlp.org/content/10/15/1917.full.html\#ref-list-1

License

Email Alerting

Service

Receive free email alerts when new articles cite this article - sign up in the box at the top right corner of the article or click here.

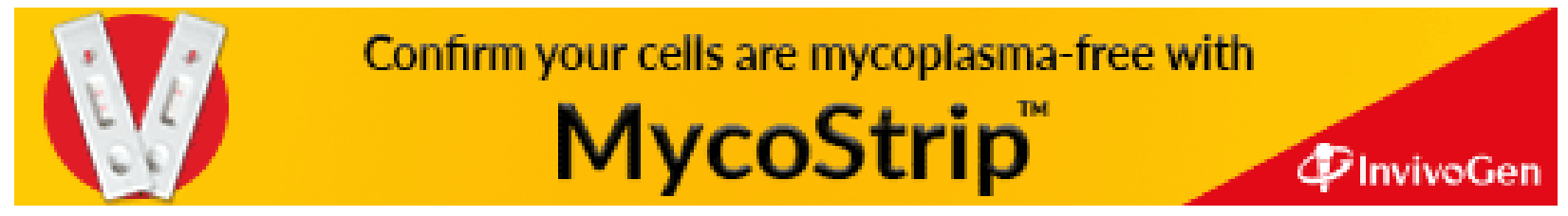

